\title{
SEBASTIANIN TAHTOA TULKITSEMASSA: SYVÄSTI KEHITYSVAMMAISEN SOSIAALIHUOLLON ASIAKKAAN MAHDOLLISUUDET VAIKUTTAA OMAAN ARKEENSA
}

Sonja Miettinen: VTT, tutkija, Kebitysvammaliitto

sonja.miettinen@kvl.ji

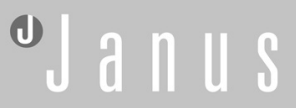

Janus vol. 29 (4) 2021, 349-365

Tiivistelmä

Vaikka kehitysvammaisten ihmisten itsemääräämisoikeus tunnustetaan nykyisin laajasti, emme ole vielä saavuttaneet yhteisymmärrystä siitä, mitä kyseinen oikeus tarkoittaa silloin, kun kehitysvamma tuottaa hyvin pitkälle meneviä rajoitteita henkilön kykyyn kommunikoida ja tehdä itsenäisiä päätöksiä. Tämän artikkelin tavoitteena on empiirisen tapaustutkimuksen keinoin kuvata "syvästi" kehitysvammaisiksi määriteltyjen henkilöiden tapaa harjoittaa itsemääräämistä omassa arjessaan. Artikkelissa sekä käsitteellistetään että havainnollistetaan näiden ihmisten ulottuvilla olevia itsemääräämisen käytäntöjä. Lisäksi artikkeli tuo esiin tarpeen kehittää sosiaalihuollon toimintakäytäntöjä laajasti toisten tuesta ja hoivasta riippuvaisten ihmisten itsemääräämisen tukemiseksi.

\section{JOHDANTO}

Itsemääräämisoikeus on keskeinen ihmisoikeus, joka sekä YK:n vammaisten oikeuksien sopimuksen että kansallisen lainsäädännön mukaan kuuluu myös kehitysvammaisille henkilöille (Sosiaali- ja terveysministeriö 2017; Suomen YK-liitto 2015; perustuslaki 1999/731; laki sosiaalihuollon asiakkaan asemasta 2000/812; laki kehitysvammaisten erityishuollosta 1977/519). Kehitysvammaiset ihmiset kuitenkin kohtaavat monitahoisia haasteita pyrkiessään harjoittamaan itsemääräämisoikeuttaan. Yhtäältä nämä haasteet juontuvat kehitysvammaisuudesta ja siihen sisältyvistä kognitiivisista ja kommunikatiivisista rajoitteista. Toisaalta kysymys on myös ympäristön asenteista. Kehitysvammadiagnoosin on perinteisesti ajateltu tarkoittavan, etteivät kehitysvammaiset ihmiset kykene hallitsemaan omaa elämäänsä miltään

osin. Näin ollen heille ei myöskään aina tarjota asianmukaisia mahdollisuuksia osallistua päätöksentekoon (ks. esim. Finlay ym. 2008a; Blanck \& Martinis 2015).

Nämä haasteet ovat epäilemättä kaikkein suurimmillaan silloin, kun henkilö on kehitysvammaisuuden vaikeusastetta kuvaavalla asteikolla määritelty "syvästi" kehitysvammaiseksi. Kyseisessä tilanteessa henkilön kyky ymmärtää ja käyttää puhuttua kieltä on äärimmäisen rajallinen. Hän kykenee parhaimmillaankin ymmärtämään puheesta vain perustasoisia kehotuksia ja käyttämään kieltä ainoastaan hyvin yksinkertaisten pyyntöjen esittämiseen (WHO 1992, 179). Syvästi kehitysvammainen ihminen ei myöskään kykene kommunikoimaan millään yleisesti tunnetulla puhetta tukevalla tai korvaavalla kommunikaatiomenetelmällä kuten 
viittomilla tai kuvilla. Sen sijaan hän ilmaisee itseään ilmeillä, eleillä, liikkeillä ja äännähdyksillä, joiden merkityksen ymmärtäminen vaatii usein läheisempää tutustumista kyseiseen yksilöön ja tiedon jakamista hänen kanssaan toimivien tahojen välillä (ks. esim. Porter ym. 2001).

Waren (2004) mukaan useimmat syvästi kehitysvammaiset henkilöt kykenevät tällaisten ei-kielellisten ilmausten avulla tuomaan esiin henkilökohtaisia preferenssejään eli ilmaisemaan mistä pitävät ja mistä eivät pidä, edellyttäen, että ympärillä on ihmisiä, jotka ovat kykeneviä tulkitsemaan näitä ilmauksia. Preferenssien ilmaiseminen on kuitenkin eri asia kuin omatoiminen eri vaihtoehtojen välillä valitseminen. Etenkin silloin, kun päätöksenteko vaatii kykyä hahmottaa abstrakteja, monimutkaisia tai tulevaisuuteen sijoittuvia asiakokonaisuuksia, on syvästi kehitysvammaisten henkilöiden usein mahdotonta tehdä valintaa itsenäisesti.

Syvästi kehitysvammaisten henkilöiden itsemääräämisoikeutta koskien on esitetty, että sen ei pitäisi katsoa kategorisesti sulkevan ulos henkilön etuun perustuvaa päätöksentekoa. Toisin sanoen muilla ihmisillä on nähty olevan moraalinen velvollisuus tehdä heidän hyvinvointiaan turvaavia päätöksiä esimerkiksi ravitsemuksen, kuntoutuksen ja lääketieteellisten toimenpiteiden tarpeisiin liittyen myös ilman heidän suunnaltaan tulevia aloitteita. (Esim. Vorhaus 2013.) Tällaiset hoivan ja huolenpidon tarpeet eivät kuitenkaan välttämättä tarkoita, etteikö henkilöä voisi ainakin jossain määrin osallistaa päätöksentekoon eri tilanteissa.
Syvästi kehitysvammaisten henkilöiden itsemääräämisen edistämisen esteenä on kuitenkin epätietoisuus tavoista, joilla he voisivat osallistua päätöksentekoon. Toistaiseksi tästä aiheesta on olemassa vain muutamia yksittäisiä tutkimuksia (Ware 2004; Watson 2016; Björnsdóttir ym. 2018). Syvästi kehitysvammaisten henkilöiden itsemääräämisoikeutta koskevan tutkimuksen keskeisenä haasteena on riittävän inklusiivisen autonomian määritelmän löytäminen. Valtaosa länsimaisen filosofian tarjoamista autonomiaa kuvaavista käsitteistä on kytketty yksilöön ja hänen älylliseen kyvykkyyteensä, ja ne sulkevat näin ollen vaikeimmin kehitysvammaiset henkilöt ulkopuolelleen (Björnsdóttir ym. 2018).

Edes viime vuosina vammaiskentän toimijoiden piirissä muotisanaksi muodostunut tuetun päätöksenteon malli ei tarjoa täysin tyydyttävää ratkaisua (Bigby ym. 2017, 235; Watson 2016). Tuetulla päätöksenteolla viitataan tavallisesti tilanteeseen, jossa kehitysvammainen henkilö on viimekätinen päätöksentekijä, mutta hän värvää perheenjäseniä, ystäviä tai muita luotettuja henkilöitä selventämään hänelle vaihtoehtoja ja ongelmia, jotta voisi muodostaa oman kantansa käsiteltävänä olevaan asiaan (Blanck \& Martinis 2015,26).Tällainen tuki ei kuitenkaan auta ylittämään niitä itsenäisen päätöksenteon vaikeuksia, joita syvästi kehitysvammaiset henkilöt kohtaavat.

Lisäksi kehitysvammaisten henkilöiden itsemääräämisen edistämisessä huomio kohdistetaan usein suuriin päätöksiin kuten missä ja kenen kanssa asuu, vaikka valinnanvapautta voitaisiin varsinkin syvästi ja vaikeasti kehitysvam- 
maisten henkilöiden kohdalla kaikkein nopeimmin lisätä arkipäivän alueilla ja sen toistuvissa toiminnoissa (Finlay ym. 2008a). Tässä artikkelissa huomio kohdistuu juuri näihin jokapäiväisen elämän valintoihin. Tavoitteena on kuvata syvästi kehitysvammaisten henkilöiden itsemääräämisen käytäntöjä analysoimalla Sebastianiksi nimetyn, ryhmäkodissa asuvan nuoren miehen elämää kuvaavaa etnografista aineistoa. Artikkelissa tarkastellaan yhtäältä sitä, millä tavalla henkilö, jolla ei ole kykyä kielelliseen kommunikaatioon ja itsenäisiin valintoihin, voi omassa arjessaan harjoittaa itsemääräämistä, toisaalta sitä, millä tavalla hänen arkeaan kehystävät instituutiot tukevat hänen toimijuuttaan.

Teoreettisella tasolla artikkeli nojaa ensisijaisesti Martha Nussbaumin (2006) toimintamahdollisuuksien teoriaan. Koska teoria pikemminkin luo suuntaviivoja syvästi kehitysvammaisten henkilöiden itsemääräämisen käytäntöjen tunnistamiseen kuin tarjoaa valmiita määritelmiä, sitä täydennetään artikkelissa kehollisten tahdonilmausten, kunnioituksen ja responsiivisuuden käsitteillä Sara Ruddickin (1996) ja Joanne Watsonin (2016) käsitteellisiä kehitelmiä hyödyntäen. Artikkelin ensimmäinen puolisko kuvaa tarkemmin kyseistä teoreettista ja käsitteellistä viitekehystä. Loppuosa tarkastelee empiiristä aineistoa sen valossa.

Artikkelissa käytettyä vammaisuuden käsitteistöä on tarpeen lyhyesti perustella, koska nykyisin vammaiskulttuurissa vahvana virtauksena ilmenevän ajattelutavan mukaan erilaisiin lääketieteellisiin diagnooseihin perustuvien leimojen käyttöä pitää välttää. Tällais- ten leimojen ajatellaan peittävän alleen ihmisyksilöt. Vaikka tässä artikkelissa pyritään näkemään yksilö ennen diagnoosia, syvän kehitysvammaisuuden kategoriaan viittaamisen katsotaan olevan perusteltua siinä mielessä, että tarvitaan jokin termi, joka mahdollistaa näiden henkilöiden erityisistä ja heikosti tunnetuista tarpeista puhumisen (ks. myös Watson 2016, 2).

\section{KOHTI INKLUSIIVISTA}

\section{ITSEMÄÄRÄÄMISEN KÄSITETTÄ}

\section{Syvästi kehitysvammaisen henkilön \\ itsemääräamisoikeus \\ toimintamahdollisuutena}

Martha Nussbaumin (2006) toimintamahdollisuuksien teoria on teoria oikeudenmukaisuudesta, jonka ytimessä on ajatus kaikkien ihmisten yhdenvertaisesta oikeudesta elää ihmisarvon mukaista elämää. Näin ollen yksilön moraalinen status ei tämän teorian valossa ole riippuvainen hänen kyvyistään, sukupuolestaan, ihonväristään tai muusta henkilökohtaisesta ominaisuudesta. Teoriassa määritellään myös, millaisia elinolosuhteita ihmisarvon mukainen elämä edellyttää. Nussbaum nimeää kymmenen inhimillistä toimintamahdollisuutta (capabilities), jotka yksilöllä on oltava, jotta ihmisarvon mukainen elämä voi toteutua.

Yksi näistä toimintamahdollisuuksista on itsemäärääminen tai Nussbaumin termein ilmaistuna "käytännön järki" (practical reason). Se tarkoittaa kykyä "muodostaa käsitys hyvästä (to form a conception of the good)" ja "käyttää kriittistä pohdintaa oman elämän suunnitteluun (to engage in critical reflection about 
the planning of one's life)" (Nussbaum $2006,77)$. Kyse on toisin sanoen valinnoista ja vapaudesta. Kyseisen toimintamahdollisuuden liittäminen keskeisten inhimillisten toimintamahdollisuuksien listaan tarkoittaa, että itsemäärääminen nähdään olennaisena elämänlaadun ulottuvuutena ja kaikkien yhteiskunnan jäsenten perusoikeutena.

Toimintamahdollisuudet muodostuvat yhtäältä henkilökohtaisista voimavaroista, toisaalta ympäröivän yhteiskunnan tarjoamista mahdollisuuksista saavuttaa arvokkaita olotiloja ja toimintoja (Nussbaum 2011, 20-21). Toisin sanoen niillä on sekä sisäinen että ulkoinen ulottuvuus. Sisäisetkään toimintamahdollisuudet eivät ole täysin sisäsyntyisiä, vaan kehittyvät vuorovaikutuksessa ympäristön kanssa. Sosiaalisen oikeudenmukaisuuden edistäminen edellyttääkin toimintamahdollisuuksien teorian mukaan panostuksia sekä toimintamahdollisuuksien sisäisiin että niiden ulkoisiin ulottuvuuksiin. Yksilön henkilökohtaisiin voimavaroihin vaikuttavat esimerkiksi hänen kasvuympäristönsä turvallisuus ja hänen saamansa koulutus ja kuntoutus. Ulkoisia toimintamahdollisuuksia luodaan puolestaan ihmisarvoa edistävien tukimuotojen, lakien ja politiikkaohjelmien avulla.

Ihmisten henkilökohtaiset voimavarat kuitenkin vaihtelevat tavoilla, joita ei pystytä täysin kontrolloimaan. Esimerkiksi syvästi kehitysvammaiset henkilöt voivat kehittää omia itsemääräämisen kykyjään vain tiettyyn rajaan saakka. Valtaosalle kehityksen lakipiste on eikielellisin keinoin ilmaistuissa mieltymyksissä. Sen lisäksi jotkut saattavat intensiivisen kuntoutuksen turvin op- pia tekemään jonkinlaisen ei-kielellisen signaalin välityksellä valintoja konkreettisten, käsillä olevien vaihtoehtojen välillä. (Ware 2004.) Tällaiset kyvyt jäävät melko kauas alkuperäisestä käytännön järjen toimintamahdollisuuden määritelmästä. Nussbaum kuitenkin painottaa, että henkilökohtaisten kykyjen rajoitteet eivät ole hyväksyttävä syy evätä toimintamahdollisuuksia yhteiskunnan jäseniltä.Yksilön on saatava kehittää omia kykyjään niin pitkälle kuin se on suinkin mahdollista, mutta mikäli hänen ei ole mahdollista saavuttaa samaa kyvykkyystasoa kuin valtaväestö, on pohdittava keinoja mahdollistaa hänelle keskeisten inhimillisten toimintamahdollisuuksien toteutuminen (Nussbaum 2006, 194).

Toisin sanoen toimintamahdollisuuksien teoria antaa mahdollisuuden ajatella, että ihmiset voivat harjoittaa itsemääräämistä eri tavoin riippuen heidän kognitiivisista ja kommunikatiivisista kyvyistään. Se ei kuitenkaan anna suoraa vastausta siihen, miten syvästi kehitysvammaiset henkilöt toteuttavat itsemääräämistä, vaan Nussbaumin (2006 193, 195-199) aihetta koskeva pohdinta jää hyvin yleiselle tasolle. Näin ollen toimintamahdollisuuksien teoria kaipaa rinnalleen muita käsitteitä, jotka auttavat täsmentämään itsemääräämisen toimintamahdollisuuden muotoja suhteessa syvästi kehitysvammaisiin henkilöihin.

\section{Miten itsemäärääminen toteutuu syvän kehitysvammaisuuden kontekstissa?}

Björnsdóttir ja kollegat (2018) ovat esittäneet, että feministisestä tutkimuksesta peräisin oleva "relationaalisen 
autonomian" käsite auttaa perinteisiä yksilökeskeisiä autonomiamalleja paremmin hahmottamaan tapoja, joilla itsemääräämisoikeus toteutuu - tai jää toteutumatta - vaikeasti ja syvästi kehitysvammaisten henkilöiden elämässä. Kyseisen käsitteen mukaan henkilökohtainen autonomia mahdollistuu aina yksilöä kannattelevien sosiaalisten suhteiden varassa. Tämä näkemys on linjassa edellä esitellyn toimintamahdollisuuksien teorian kanssa, jossa niin ikään korostetaan, että kyky itsemääräämiseen muodostuu suhteessa ympäröivän yhteiskunnan rakenteisiin. Samalla relationaalisen autonomian käsite herättää sekin kysymyksiä. Millaiset suhteet mahdollistavat syvästi kehitysvammaiselle henkilölle asianmukaisen autonomian? Millainen rooli hänellä itsellään on toimijana näissä suhteissa?

Filosofi Sara Ruddickin (1996) käsite "kehollisiin tahdonilmauksiin kohdistuva kunnioitus ja responsiivisuus" (respect and resonsiveness to embodied willfulness)" tarjoaa yhden tavan vastata näihin kysymyksiin. Käsite kuvaa, kuinka henkilökohtaista autonomiaa voidaan edistää tilanteessa, jossa yksilö on laajasti riippuvainen toisilta ihmisiltä saadusta tuesta ja hoivasta. Käsitteen kaikki osiot - kehollinen tahdonilmaus, kunnioitus ja responsiivisuus - ovat tärkeitä tässä kontekstissa.

Kehollinen tahdonilmaus kuvaa hoivan tarvitsijan toimijuutta tavalla, joka laajentaa käsitystä inhimillisestä toimijuudesta. Se auttaa ymmärtämään, että valintojen tekeminen ja tavoitteiden jäsentäminen puhutun kielen avulla ei ole ainoa tapa ilmentää toimijuutta. Tällainen abstrahoiva ja rationalisoiva tahtominen on pikemminkin osa laa- jempaa jatkumoa, johon sisältyy myös kielellisten ilmaisujen ulkopuolisina liikkeinä, tavoitteluina, aloitteina ja vastustamisina ilmenevä tahtominen.

Vaikka Ruddick (1996) pyrkii tekstissään korostamaan erityisesti pienten lasten kykyä omatahtoisuuteen, hän ei kuitenkaan sido kehollisen tahdonilmauksen käsitettä varhaislapsuuden ikävaiheeseen. Onhan myös aikuisia, joille keholliset tahdonilmaukset muodostavat esimerkiksi kehitysvamman tai pitkälle edenneen keskushermoston sairauden tai muistisairauden vuoksi pääasiallisen tavan tuoda esille omia tavoitteitaan. Kyse on myös yleisinhimillisestä ominaisuudesta siinä mielessä, että tahtomme on aina sidoksissa kehoomme. Äärimmäisenä esimerkkinä tästä sidoksesta on toisen ihmisen alistaminen fyysisen väkivallan keinoin.

Kunnioitus ja responsiivisuus kuvaavat puolestaan asennoitumista ja toimintaa, joita hoivan tarvitsijan itsemääräämisoikeuden turvaaminen vaatii hoivan antajilta. Kunnioitus sisältää ajatuksen toisen ihmisen fyysisestä ja psyykkisestä koskemattomuudesta. Se edellyttää hoivan antajilta itsehillintää ja pidättyvyyttä, sulkien pois niin tarpeettoman puuttumisen toisen ihmisen elämänvalintoihin, ylimitoitetut rajoittamistoimenpiteet kuin väkivallalla tai sen uhalla pakottamisenkin.

Kunnioitus ei kuitenkaan yksin riitä, kun henkilöllä on laajat tuen ja hoivan tarpeet. Tällöin tarvitaan Ruddickin (1996) mukaan myös responsiivisuutta. Responsiivisuus on proaktiivista toimintaa, josta Ruddickin lisäksi on kirjoittanut myös Watson (2016), määritellen sitä erityisesti suhteessa syvästi 
kehitysvammaisiin henkilöihin. Hänen mukaansa responsiivisuus tarkoittaa tässä yhteydessä henkilön sanattomien tahdonilmausten tarkkailemista, tulkitsemista ja täytäntöönpanoa. Näitä kaikkia vaiheita tarvitaan, jotta syvästi kehitysvammainen henkilö voisi vaikuttaa omaan elämäänsä. Näihin responsiivisuuden elementteihin on kuitenkin vielä tarpeen lisätä tahdonilmausten esiin kutsuminen eli työskentely sen hyväksi, että syvästi kehitysvammaiset henkilöt kykenisivät mahdollisimman laajasti ilmaisemaan omaa tahtoaan onhan kyseessä kyky, joka vaatii omien taipumusten tuntemista ja luottamusta omiin mahdollisuuksiin saada äänensä kuuluviin.

Tässä artikkelissa on nyt eri lähteitä yhdistellen ja toisiaan täydentäen muodostettu täsmällisempi määritelmä tavasta, jolla syvästi kehitysvammaiset aikuiset voivat toteuttaa itsemääräämisoikeuttaan omassa arkielämässään. Kun itsemääräämisoikeutta lähestytään toimintamahdollisuuksien teorian näkökulmasta, sen nähdään kuuluvan jossain muodossa myös laajasti toisten tuesta ja hoivasta riippuvaisille ihmisille ja sen toteutumista tarkastellaan kohdistamalla huomio yksilön ja hänen ympäristönsä vuorovaikutukseen. Kehollisen tahdonilmauksen käsite kuvaa syvästi kehitysvammaisen henkilön omaa roolia omannäköisen elämän luomisessa. Se herkistää meidät ei-kielellisen kommunikaation havaitsemiseen ja auttaa näkemään sen yhtenä väylänä omaan tahdon ilmaisemiseen. Kunnioituksen ja responsiivisuuden käsitteet auttavat puolestaan tarkemmin määrittelemään, mitä omannäköisen elämän mahdollistaminen syvästi kehitysvammaisellehenkilölle edellyttää hänen ympäristöltään. Ne alleviivaavat hoivan antajien asennoitumisen ja toiminnan merkitystä tässä prosessissa.

\section{ETNOGRAFIAA SYVÄSTI \\ KEHITYSVAMMAISTEN AIKUISTEN ARJESTA}

\section{Tutkimusaineisto}

Artikkelin empiirinen tutkimusaineisto muodostuu vuosina 2014-2016 toteutetusta etnografisesta kenttätyöstä, joka oli osa Vaikea kehitysvammaisuus ja hyvä elämä -tutkimusprojektia. Tutkimusprojektia rahoittivat Suomen Akatemia (SA275988) ja Koneen säätiö (henkilökohtaiset apurahat). Tutkimustiimiin kuuluivat kirjoittajan lisäksi professori SimoVehmas ja KTT Reetta Mietola. Tutkimusprojektissa tarkasteltiin kaikkein vaikeimmin kehitysvammaisten aikuisten arkea ja sitä kehystäviä institutionaalisia käytäntöjä sekä "hyvän" elämän edellytyksiä.

Ennen kenttätyön aloittamista tutkimusprojekti kävi läpi Helsingin yliopiston eettisen ennakkoarvioinnin. Tämän jälkeen ryhdyttiin etsimään kehitysvammaisia henkilöitä, joiden kanssa kenttätyö voitaisiin toteuttaa. Ensimmäiseksi tutkijat ottivat yhteyttä kunnan vammaispalveluihin ja pyysivät sieltä tutkimusluvan. Tämän jälkeen otettiin yhteyttä palveluntuottajaorganisaatioihin ja haettiin tutkimuslupaa myös niiltä kunkin organisaation tutkimuslupakäytäntöjä noudattaen. Palveluntuottajaorganisaatiot ohjasivat sitten tutkijat niihin yksiköihin, joista löytyy aikuisikäisiä, kiinnostuksen kohteena olevaan vammaiskategoriaan kuuluvia henkilöitä. Osallistujista neuvoteltiin ensin yksiköiden johtajien kanssa ja sen 
jälkeen lähityöntekijöiden ja omaisten kanssa. Syvästi kehitysvammaisten henkilöiden osallistumiselle pyydettiin lupa heidän omaisiltaan tai läheiseltä työntekijältä. Lisäksi haastatteluihin osallistuvilta omaisilta ja työntekijöiltä pyydettiin kirjallinen suostumus ennen haastattelua. Havainnointipaikkojen muulta henkilökunnalta pyydettiin suullinen suostumus tutkimukseen.

Kehitysvammaisia osallistujia oli yhteensä kuusi. Kenttätyö toteutettiin kolmessa jaksossa. Jokaisessa jaksossa seurattiin kahta kehitysvammaista osallistujaa siten, että yksi kenttätutkijoista seurasi yhtä osallistujaa ja toinen tutkija toista. Jokaista kehitysvammaista osallistujaa seurattiin noin kolmen kuukauden ajan, kaksi päivää viikossa ja neljä tuntia päivässä. Havainnointia toteutettiin kaikissa heidän arkeaan kehystävissä ympäristöissä, mukaan lukien ryhmäkodit, päivätoimintakeskukset ja erilaiset kuntoutusympäristöt. Havainnot niihin sisältyvine tulkintoineen kirjattiin muistiin käsin havainnoinnin aikana heti kun tämä oli mahdollista ja kirjoitettiin myöhemmin puhtaaksi tekstinkäsittelyohjelmalla.

Tutkijat sitoutuivat kenttätyössä yhtä aikaa sekä tunnustamaan tutkimukseen osallistuvien henkilöiden yhtäläisen ihmisarvon että huomioimaan heidän yksilöllisen erilaisuutensa Iris Marion Youngin (1997) "epäsymmetrisen vastavuoroisuuden" (asymmetrical reciprocity) periaatetta noudattaen (ks. Mietola ym. 2017). Tätä periaatetta noudatettiin kenttätyössä ensinnäkin siten, että tutkijat asennoituivat kehitysvammaisiin osallistujiin kommunikoivina subjekteina, vaikka he eivät kykenekään ilmaisemaan itseään kielellisesti. Toisin sanoen tutkijat kiinnittivät huomiota heidän eleisiinsä, ilmeisiinsä ja liikkeisiinsä eri tilanteissa ja muodostivat tulkintoja niiden merkityksestä. Näiden tulkintojen muodostaminen edellytti paitsi pidempiaikaista henkilökohtaista kontaktia vammaisten osallistujien kanssa, myös keskustelua heidät hyvin tuntevien ihmisten kanssa. Lisäksi tutkijat olivat osallistuneet puhetta korvaavien ja tukevien kommunikaatiomenetelmien perehdytykseen ennen kenttätyötä parantaakseen omia vuorovaikutus- ja tulkintakykyjään. Vaikka lähiihmisten tulkkausapu oli suureksi avuksi osallistujien yksilöllisiin kommunikaatiorepertuaareihin tutustumisessa, tutkijat omaksuivat viimekätisen vastuun kehitysvammaisia osallistujia koskevista tulkintojen tekemisestä vertaamalla omia havaintoja ja eri tahoilta saatua tietoa sen sijaan, että olisivat yksinkertaisesti omaksuneet lähi-ihmisten tulkinnat (prosessista tarkemmin ks. Mietola ym. 2017, 270-271).

Tavoitteena oli pyrkiä muodostamaan jonkinlainen ymmärrys - vaikka osittainen ja hatarakin - kehitysvammaisten osallistujien kokemuksista. Tällöin pelkkä pyrkimys asettua toisen asemaan ei riitä. Kuten Young $(1997,48)$ huomauttaa, kuvitellessamme itsemme jonkun heikommassa asemassa olevan ihmisen asemaan voivat omasta etuoikeutetusta positiostamme juontuvat ennakko-oletukset saada näkemään tuon ihmisen tilanteen vääristyneellä tavalla. Ei siis pidä tehdä oletuksia toisesta sen perusteella, mitä itse uskon tuntevani ja ajattelevani, jos olisin hänen asemassaan. Sen sijaan on kuunneltava hyvin tarkasti, mitä hän ilmaisee omista tarpeistaan ja näkemyksistään ja oltava valmis yllättymään. 
Kenttätyön aikana tutkijat pyrkivät rakentamaan kunnioittavaa ja vastavuoroista vuorovaikutusta kehitysvammaisten osallistujien kanssa myös kasvokkaisissa kohtaamisissa (ks. Mietola ym. 2017, 268-270). Tutkijat antoivat heidän määritellä sekä läsnäolonsa rajat että tavat, joilla tutkijat olivat kontaktissa heidän kanssaan. Samalla tutkijat pyrkivät olemaan heille mahdollisuuksien mukaan eri tavoin avuksi, ja usein ylimääräiselle auttavalle käsiparille olikin tarvetta. Usein tutkijat yksinkertaisesti vain pitivät osallistujille seuraa - viettiväthän nämä arjessaan päivittäin pitkiä aikoja yksin odottaen työntekijöidensä saapuvan suorittamaan seuraavaa tehtäväänsä.

Osallistuvan havainnoinnin lisäksi tutkimushankkeessa haastateltiin jokaisen osallistujan lähimpiä omaisia sekä heidän lähityöntekijöitään ryhmäkodeissa ja päivätoimintakeskuksissa. Haastatteluissa käsiteltiin kehitysvammaisia osallistujia henkilöinä, heidän elämäänsä ja keskeisiä arjen konteksteja kulloinkin haastateltavana olevan henkilön näkökulmasta sekä hänen tietämyksensä ja tulkintojensa pohjalta. Haastattelut kestivät noin tunnin ja ne nauhoitettiin ja litteroitiin. Haastatteluja toteutettiin kaikkiaan 19.

Sebastianin tapaus esimerkkinä syvästi kehitysvammaisten henkilöiden itsemäärämisen mahdollisuuksista

Tässä artikkelissa tarkastelu on rajattu “tiheän kuvauksen” (Geertz 1973, luku 1) mahdollistamiseksi yhtä osallistujaa koskevaan havainnointi- ja haastattelumateriaaliin. Yhteen tapaukseen keskittyminen antaa mahdollisuuden paneutua aineiston pieniin yksityiskohtiin ja niihin kytkeytyviin merkitysrakenteisiin, mikä on erityisen hedelmällistä silloin, kun tutkimukseen osallistuva henkilö kommunikoi pääasiassa yksilöllisillä ja usein hyvin hienovaraisilla kehonkielen ilmaisuilla (ks. myös Ferguson \& Ferguson 2001). Kyseessä on parikymppinen syvästi kehitysvammainen ja monivammainen nuori mies, jota kutsutaan tässä artikkelissa Sebastianiksi (pseydonyymi).

Sebastianin tapaus on valittu lähempään tarkasteluun useammasta syystä. Ensinnäkin Sebastianin tapaus valottaa, millaisia toimijuuden kykyjä syvästi kehitysvammaiset henkilöt voivat kehittää, vaikka eivät saavuttaisikaan itsenäisten valintojen tekemisen tasoa. Tosin tässä yhteydessä on tarpeen mainita, että Sebastianilla on epäilemättä ollut elämänsä aikana paremmat mahdollisuudet kehittää henkilökohtaisia kykyjään liikkeeseen, kommunikaatioon ja tahtomiseen kuin monella muulla syvästi kehitysvammaisella henkilöillä hänen perhetaustastaan ja saamastaan kuntoutuksesta ja koulutuksesta johtuen. Toiseksi Sebastianin tapaus valottaa hyvin nykyisen elinympäristön vaikutusta syvästi kehitysvammaisen henkilön mahdollisuuksiin harjoittaa itsemääräämistä. Sebastianin päivittäisestä tuesta ja hoivasta vastaavat organisaatiot muodostivat erilaisia konteksteja, joissa hänen toimijuutensa tukemiseen suhtauduttiin toisistaan poikkeavin tavoin.

Sebastian käyttää pyörätuolia ja pystyy jonkin matkaa kelaamaan ja ohjaamaan sitä käsillään. Kaikissa muissa toimissaan hän tarvitsee muiden apua. Sebastianin verbaalinen kommunikaatio rajoittuu yksi- tai kaksitavuisiin äännähdyksiin, joista ei muodostu mitään tunnettuja 
sanoja. Sebastian ei myöskään aktiivisesti käytä mitään yleisesti tunnettua vaihtoehtoista kommunikaatiomenetelmää, vaikka hänelle on tarjottu aktiivisesti muun muassa kommunikointikuvia. Sebastianilla on kuitenkin ympärillään ihmisiä,jotka pystyvät tunnistamaan ja tulkitsemaan hänen erilaisia ei-kielellisiä ilmaisujaan.

Sebastianin asuinympäristö on nykyisen laitoshoidon purkua painottavan vammaispolitiikan oloissa tyypillinen lapsuudenkodin ulkopuolella asuville syvästi tai vaikeasti kehitysvammaisille henkilöille (ks. esim. Paara 2005; Sosiaali- ja terveysministeriö 2012). Sebastian asuu pienessä, tavanomaiselle asuinalueelle rakennetussa ryhmäkodissa. Hän on muuttanut ryhmäkotiin vanhempiensa luota ja oli kenttätyön alkaessa ehtinyt asua siellä jo muutaman vuoden. Vanhemmat pitävät häneen edelleen säännöllisesti yhteyttä. He käyvät vierailulla Sebastianin luona, vievät hänet välillä viikonlopuksi omaan kotiinsa ja osallistuvat Sebastianin palvelujen organisointiin ja valvovat niiden laatua. Asukkaita Sebastianin ryhmäkodissa on kuusi. Kaikki ovat vaikeasti tai syvästi kehitysvammaisia. Asukkailla on ryhmäkodissa omat huoneet pesutiloineen.

Sebastian ei kykene tekemään työtä, mutta hän osallistuu arkipäivisin toisessa palveluyksikössä järjestettyyn päivätoimintaan, jonne hän kulkee taksilla. Sebastian osallistuu lisäksi kaksi kertaa viikossa kuntoutukseen. Henkilökohtaista avustajaa hänellä ei ole, vaan hän saa suurimman osan päivittäin tarvitsemastaan laajasta tuesta ryhmäkotinsa ja päivätoimintakeskuksensa henkilökunnalta. Syvästi kehitysvammaiset henkilöt rajataan usein henkilökohtai- sen avun ulkopuolelle, sillä Suomessa tämän vammaisen henkilön itsenäistä elämää tukevan palvelun saamisen ehtona on, että henkilöllä on voimavaroja määritellä avun sisältö ja toteutustapa (Laki vammaisuuden perusteella järjestettävistä palveluista ja tukitoimista 1987/380). Sebastian ei pysty tähän yksin.

Sebastianin elämää kuvaava tutkimusaineisto on analysoitu edellisessä luvussa esitellyn teoreettisen ja käsitteellisen viitekehyksen varassa. Analyysin ensimmäisessä vaiheessa tavoitteena oli tunnistaa Sebastianin henkilökohtaiset toimijuuden kyvyt (so. sisäiset toimintamahdollisuudet) huomioiden keholliset tahdonilmaukset yhtenä toimijuuden ilmenemismuotona. Kaikkia Sebastianille mahdollisia tapoja ilmaista tahtoaan on tässä artikkelissa esitettyyn analyysiin tuskin voitu tavoittaa, onhan syvästi kehitysvammaisten henkilöiden koko kykypotentiaalin arvioiminen äärimmäisen vaikeaa. Sen sijaan analyysi rajautuu niihin tahdonilmauksiin, jotka Sebastianilla oli kenttätyön ajankohtana käytössään ja joita hän toistuvasti käytti.

Analyysin seuraavassa vaiheessa huomio kohdistuu Sebastianin elinympäristöön (so. ulkoisiin toimintamahdollisuuksiin). Elinympäristön osalta tarkastelu on rajattu päivätoimintakeskukseen ja ryhmäkotiin, sillä nämä muodostavat ne kontekstit, joissa Sebastian suurimman osan ajastaan viettää. Päivätoimintakeskus tuottaa osallisuutta ja omatoimisuutta tukevia palveluja ja ryhmäkoti asumista tukevia palveluja, mutta molempien organisaatioiden julkilausutuissa toimintaperiaatteissa huomioidaan asiakkaiden itsemääräämisoikeus. Analyysissä tarkastellaan, kuinka tätä 
oikeutta tuetaan käytännössä käyttäen kriteereinä edellä määriteltyjä kunnioituksen ja responsiivisuuden periaatteita.

\section{Sebastian omatahtoisena toimijana}

Edellä todettiin, että Sebastian ei kykene muodostamaan yhtään kokonaista sanaa. Miten hän sitten tuo esille omaa tahtoaan? Ensinnäkin hänellä on hyvin ilmeikkäät kasvot. Sebastianin kasvonilmeistä ympärillä olevat ihmiset saattavat tehdä päätelmiään hänen reaktioistaan. Hän ilmaisee tyytyväisyyttään säteilevällä hymyllä. Pahastuessaan hän puolestaan vakavoituu ja hänen kasvonsa punehtuvat. Pettymyksen kyyneleet kihoavat toisinaan hänen silmiinsä.

Kasvojen ilmeiden lisäksi Sebastian kommunikoi eleillä ja liikkeillä. Hänen käsivarsiensa ja kämmentensä motoriikka luo hänelle monenlaisia mahdollisuuksia toimijuuteen. Hän kykenee kelaamaan pyörätuoliaan kohti häntä kiinnostavia ihmisiä ja objekteja. Hän kykenee tarttumaan esineisiin, jotka häntä kiinnostavat ja käden huitaisulla torjumaan sellaiset hänelle tarjotut esineet, jotka eivät häntä kiinnosta. Hän ottaa käsillään kontaktia myös ihmisiin. Hän saattaa nipistää toista, kun tämä ei ole toiminut hänen toivomallaan tavalla. Toisaalta hän myös halaa ja lähettää lentosuukkoja ihmisille, joista pitää.Joskus Sebastian tuo tahtoaan esiin myös ylävartalon liikkeillä. Jos hän huomaa, että häntä ollaan viemässä suuntaan, jonne hän ei halua mennä, hän heittäytyy pyörätuolissaan rajusti taaksepäin.

Kolmanneksi Sebastian kommunikoi katseellaan. Kun hän lähestyy ihmisiä kelaamalla pyörätuolillaan heidän vie- reensä hän samalla muodostaa heihin kiinteän katsekontaktin. Hän kiinnittää katseensa myös kiinnostaviin objekteihin, saattaen katsella pitkiä aikoja tiettyjä kuvia kirjoissa tai seinällä.

Vaikka Sebastianin lähi-ihmiset luottivatkin omaan kykyynsä tulkita Sebastianin ilmaisuja useimmissa tilanteissa, Sebastianilla on myös joitakin ilmaisuja, joiden merkityksestä ei oltu varmoja. Sebastian usein "juttelee" toistelemalla tiettyjä tavuja. Kenttätyön aikana näiden äänteiden merkityksestä esitettiin erilaisia arvailuja, mutta jopa Sebastianin vanhemmat myönsivät, etteivät he tiedä, mihin Sebastian juttelullaan pyrkii.

Vaikka Sebastianin kehollisiin tahdonilmauksiin sisältyykin tiettyä vaikeatulkintaisuutta ne kuitenkin muodostavat hänelle kanavan tuoda esiin omaa tahtoaan. Kysymys on tällöin enemmän preferensseistä kuin varsinaisista valinnoista (Ware 2004). Päivätoimintakeskuksessa Sebastianille on luotu useasti tilanteita myös valintojen tekemisen harjoitteluun, mutta ainakaan vielä kenttätyön aikana hänen ei havaittu tekevän mitään omaa valintaa ilmaisevaa elettä. On vaikeaa arvioida, voisiko hän oppia tekemään valintoja tällä tavalla tulevaisuudessa. Toimintamahdollisuuksien teorian näkökulmasta on tärkeää, että hänen henkilökohtaisten itsemääräämisen kykyjensä kehitystä tuetaan niin pitkälle kuin mahdollista. Yhtä tärkeää on kuitenkin kehittää muita tapoja ottaa hänen toiveensa huomioon niin kauan kuin hänellä ei ole kykyä tehdä valintoja sanan varsinaisessa merkityksessä. 
Preferenssien ilmaiseminen voidaan nähdä yhtenä tapana harjoittaa itsemääräämistä, sillä ne edustavat henkilön mieltymyksiä suhteessa eri vaihtoehtoihin. Millaisia Sebastianin mieltymykset sitten ovat? Hänellä on useampia erilaisia mieltymyksiä. Osa niistä koskee tiettyjä aktiviteetteja. Esimerkiksi riippumatossa keinuminen on yksi Sebastianille erityisen mieluisista aktiviteeteista. Hänet asetetaan riippumattoon sivuttain istuma-asentoon niin että hänen jalkansa ylettyvät maahan. Riippumattoon päästyään Sebastian alkaa keinuttaa itse itseään aktiivisesti jaloillaan ja saa näin aikaan hyvinkin vauhdikasta keinuntaa. Samalla hänen kasvoilleen leviää riemastunut hymy. Näillä perusteilla Sebastianin ympärillä olevat ihmiset saattoivat todeta, että riippumatossa keinuminen kuuluu hänen preferensseihinsä.

Riippumaton lisäksi Sebastian pitää muun muassa pallottelusta. Ihan mikä tahansa pallo ei Sebastianille käy, mutta silloin kun pallo on hänen näkökulmastaan oikeanlainen, hän käsittelee sitä omaehtoisesti ja innostuneesti. Hän heittää sitä itse ilmaan ja kun toinen heittää pallon hänelle, hän nappaa sen käsiinsä.Tällainen pallottelu saa hänen kasvonsa säteilemään. Jos pallo sattuu vierimään lattialle, hän kelaa sen perään ja noukkii sen taidokkaasti lattialta yhdellä kädellä voidakseen jatkaa pallottelua. Kenttätyön aikana pallo olikin ainoa esine, jonka vuoksi Sebastian motivoitui moisiin toimintarajoitteisiinsa nähden hyvin vaativiin suorituksiin.

Sebastian nauttii myös voimakkaiden äänten aikaansaamisesta. Usein nähdessään avoimen oven hän kelaa sen luo, paukauttaa sen kiinni ja nauraa ilkikurisesti päälle. Hän kolisuttelee ja rämisyttelee mielellään esineitä muutenkin.

Kaikki Sebastianin preferoimista aktiviteeteista eivät suinkaan ole liikunnallisia tai kovaäänisiä. Kenttätyön aikana hän esimerkiksi rauhoittui silloin tällöin katsomaan eräiden omien, ryhmäkotiin hänen mukanaan tuotujen lastenkirjojen värikkäitä kuvituksia. Hän keskittyi näihin kuviin hyvin intensiivisesti, mikä kielii siitä, että niillä on hänelle jokin erityinen merkitys. Hän myös saattoi asettua paikoilleen kuuntelemaan ääneen lukua, vaikkei kykenekään ymmärtämään luettua sisältöä.

Sebastian toimii myös tavoilla, jotka ilmentävät sosiaalisia suhteita koskevia mieltymyksiä. Kenttätyön aikana hän käyttäytyi hyvin sosiaalisesti etsiytyen aktiivisesti vuorovaikutukseen toisten ihmisten kanssa. Hän kelasi toisen luo, otti katsekontaktia, kosketti. Vuorovaikutus toisten ihmisten kanssa sisälsi useimmiten fyysistä kontaktia, kuten halaamista tai erityisen vastavuoroisen taputusleikin leikkimistä. Hän ylläpiti vuorovaikutusta pitkiä aikoja.

Lisäksi Sebastianilla on hyödykkeitä koskevia preferenssejä. Sebastianin isä kutsui häntä hellästi "kahvifriikiksi". Myös Sebastianin ohjaajat päivätoimintakeskuksessa ja ryhmäkodissa puhuivat hänen mieltymyksestään kahviin. Itse Sebastian ilmaisee tätä mieltymystä tarttumalla kahvimukiin välittömästi, kun se asetetaan pöydälle hänen eteensä. Hän pitelee kahvikuppia kaksin käsin ja nauttiessaan sen sisältöä äännähtää merkitsevästi ja äänekkäästi "mmm". 
Kuten yllä oleva kuvaus osoittaa, Sebastianin preferenssit ovat moninaisia ja persoonallisia, eikä niitä voi määritellä tuntematta häntä henkilökohtaisesti. Samalla on tärkeää huomioida näiden preferenssien mahdollinen muuttuminen ajassa. Uusia mieltymyksiä voi löytyä, kun ympärillä olevat ihmiset johdattavat syvästi kehitysvammaisen henkilön uusiin tilanteisiin ja seuraavat hänen reaktioitaan niissä. Sebastiankin oli löytänyt pallottelun tällä tavalla, kun hänen vanhempansa olivat kokeilleet erilaisia aktiviteetteja hänen kanssaan hänen ollessaan lapsi.

Henkilökohtaiset preferenssit ovat aina myös tilannesidonnaisia. Edellä mainittiin Sebastianin pitävän riippumatossa keinumisesta, mutta jossakin vaiheessa hän saa siitä tarpeekseen ja haluaa pois. Jos tiettyjen toimintojen suorittaminen syvästi kehitysvammaisen henkilön kanssa muodostuu rutiiniksi, jossa ei kiinnitetä huomiota siihen, mitä kyseinen henkilö tuntee ja haluaa kussakin tilanteessa, saatetaan tahattomasti rajoittaa hänen itsemääräämisoikeuttaan, vaikka nämä toiminnot perustuisivatkin hänen selvitettyihin preferensseihinsä (ks. Finlay ym. 2008b).

\section{Sebastianin hoivasuHTEET} OMANNÄKÖISEN ELÄMÄN MAHDOLLISTAJINA

Edellä on todettu, että syvästi kehitysvammaisen henkilön itsemääräämisoikeuden turvaaminen edellyttää, että hoivasuhteet, joiden varaan hänen arkensa rakentuu, ovat paitsi kunnioittavia, myös riittävän responsiivisia. Tästä näkökulmasta erityisesti Sebastianin ryhmäkodin toimintakäytännöissä on parantamisen varaa. Kenttätyön aika- na Sebastianin ryhmäkodin työntekijät noudattivat pitkälti ennalta määrättyjä, fyysisten tarpeiden tyydyttämiseen tähtäävistä toimenpiteistä muodostuvia rutiineja. Kun päivittäiset toimet - syöminen, peseytyminen, pukeminen - oli suoritettu, Sebastian jätettiin joko istumaan pyörätuoliinsa tai makoilemaan huoneeseensa.

Kun responsiivisuutta tarkastellaan prosessina, jonka vaiheita ovat kehollisten tahdonilmausten esiin kutsuminen, tarkkaileminen, tulkitseminen ja täytäntöönpano, nähdään, että ryhmäkodin toimintakäytännöt olivat puutteellisia tämän prosessin kaikissa vaiheissa. Ensinnäkään Sebastianin arkea ei aktiivisesti järjestetty hänen preferenssiensä mukaiseksi (täytäntöönpano). Kaikki aktiviteetit, jotka olivat Sebastianille tärkeitä, mutta joita hän ei voinut suorittaa omatoimisesti, loistivat hänen ryhmäkodissaan poissaolollaan.

Sebastianilla oli kyllä ryhmäkodissa oma riippumatto, pallo ja kirjoja, jotka hänen vanhempansa olivat hänelle tuoneet. Niistä ei kuitenkaan ollut hänelle käytännössä paljoakaan iloa, koska jonkun olisi pitänyt nostaa hänet riippumattoon hänelle sopivaan asentoon, jotta hän olisi voinut keinua siinä, heitellä hänelle palloa, jotta hän olisi voinut pallotella, ja lukea hänelle kirjaa ääneen ja näyttää siinä olevia kuvia, jotta hän olisi voinut nauttia lukuhetkistä. Näitä aktiviteetteja Sebastian toteutti arjessaan lähes yksinomaan päivätoimintakeskuksessa siellä työskentelevien ohjaajien avustuksella - ja osin myös tutkijansa kanssa.

Sebastian ei kykene sanallisesti vaatimaan tilanteeseensa muutosta, joten jonkun olisi pitänyt hoivatoimenpi- 
teiden välillä käydä tarkistamassa, oliko Sebastian tyytyväinen olotilaansa (tarkkaileminen ja tulkinta). Jos ryhmäkodissa olisi toimittu näin, olisi voitu huomata, kuinka Sebastian ilahtuu huoneeseen saapuvasta vieraasta ja ryhtyy innokkaasti vuorovaikutukseen hänen kanssaan. Näin Sebastian reagoi kenttätyön aikana aina tutkijansa sisääntuloon, saaden hänet ajattelemaan, että Sebastian kaipasi seuraa ja mielekästä tekemistä, vaikka oleilikin huoneessaan ulospäin rauhallisen oloisena.

Kun Sebastian oli jätetty hoivatoimenpiteiden väliajaksi istumaan pyörätuoliin, hän lähti useimmiten etsimään muita ihmisiä. Tällöin hän tavallisesti otti kontaktia tutkijaansa - olihan tämä usein lähimpänä ja hänellä oli myös aikaa Sebastianille enemmän kuin työntekijöillä. Tutkijansa silmissä Sebastian näytti etsivän seuraa myös työntekijöistään, mutta Sebastianin työntekijät eivät tuoneet millään tavoin esiin tunnistavansa Sebastianin pyrkimyksiä sosiaalisiin kontakteihin. Sebastian selvästi tiesi, että heidät voi löytää keittiöstä, ja hän näytti myös tietävän, että keittiöön oli asukkailta pääsy kielletty. Näin ollen hän toisinaan kelasi pyörätuolinsa keittiön ovensuuhun ja pysähtyi siihen. Joskus Sebastianin annettiin jäädä siihen kuuntelemaan, kun työntekijät juttelivat keskenään, ja seuraamaan heidän toimiaan. Joskus taas hänet työnnettiin takaisin olohuoneeseen ja pakotettiin pysymään siellä pistämällä pyörätuolin jarrut lukkoon.

Sebastianin kehollisten tahdonilmausten ohittaminen toistui useissa eri tilanteissa kenttätyön aikana. Kerran Sebastian esimerkiksi onnistui pyörätuolissaan aikaansa viettäessään saamaan käsiinsä pyykkikorin ja alkoi heiluttelemaan sitä, nauraen aikaansaamalleen äänelle. Tutkija arveli hänen toimivan näin keksiäkseen itselleen ajankulua - olihan hänellä hyvin vähän muita virikkeitä tarjolla. Kun työntekijät huomasivat, mitä oli tekeillä, pyykkikori otettiin Sebastianilta nuhtelujen kera pois. Siihen oli tullut vaurioita. Työntekijät kertoivat, että vastaavaa oli tapahtunut ennenkin ja että he joskus saattoivat näissä tilanteissa laittaa Sebastianin pyörätuolin jarrut lukkoon.

Sebastianin oma-aloitteiseen toimintaan olisi voitu suhtautua toisinkin. Edellä kuvatut liikkeet ja teot olisi voitu nähdä omanlaisenaan tahdonilmauksena ja pohtia, mihin Sebastian niillä pyrkii. Tällöin niihin olisi voitu myös vastata. Mikäli Sebastiania täytyy estää rikkomasta tavaroita, voitaisiin tarjota jotakin muuta mielekästä aktiviteettia tilalle.

Sen valossa, mitä Sebastianin ryhmäkotiarjesta on tähän mennessä kerrottu, ei liene yllättävää, että hänen kanssaan ei myöskään toteutettu minkäänlaisia uudenlaisia kokeiluja (esiin kutsuminen), vaan samat rutiinit toistuivat päivästä toiseen.

Sebastianin ryhmäkodissa oli kenttätyön aikana tavallista korkeammat henkilökuntaresurssit, koska yksi huone oli ilman asukasta. Tämä tarkoitti, että yhdellä työntekijällä oli työvuoronsa aikana vastuullaan kolme paljon apua tarvitsevaa asukasta. On selvää, että asukkaiden perushoiva vie tässäkin tilanteessa suurimman osan työajasta. Jäljellejääviäkään hetkiä ei kuitenkaan käytetty asukkaiden näkökulmasta mielekkään arjen luomiseen, mikä viit- 
taa siihen, että kyse ei ole pelkästään käytössä olevista resursseista vaan myös siitä, millaisia toimintakäytäntöjä organisaatioon on kehkeytynyt.

Sebastianin päivätoimintakeskuksessa oli sen sijaan kehitetty monia vaikeimmin kehitysvammaisten asiakkaiden itsemääräämisoikeutta tukevia käytäntöjä - samalla kun päivätoimintakeskus ja ryhmäkoti toimivat hyvin pitkälle toisistaan erillään ilman aktiivista keskusteluyhteyttä. Päivätoimintakeskuksen toimintakäytännöissä on nähtävissä responsiivisuuden prosessin kaikki eri vaiheet, minkä ansiosta Sebastian eli siellä selvästi aktiivisempaa, virikkeellisempää ja omaehtoisempaa arkea kuin ryhmäkodissaan.

Päivätoimintakeskuksessa Sebastianin tahdonilmausten kehitystä tuettiin ja hänen kanssaan etsittiin ja kehitettiin yhdessä uudenlaisia mieleisiä aktiviteetteja ja leikkejä. Ohjaajat tarkkailivat jatkuvasti hänen kehollisia tahdonilmauksiaan eri tilanteissa ja olivat taitavia tulkitsemaan niitä. Lisäksi he kokosivat ja jakoivat tietoa Sebastianin tavoista ilmaista itseään ja hänen henkilökohtaisista preferensseistään, minkä ansiosta myös uudet työntekijät oppivat nopeasti tuntemaan Sebastianin. Sebastianin tahdonilmauksiin reagoitiin paitsi spontaanisti käsillä olevassa tilanteessa myös toiminnan organisoinnin tasolla. Sebastianin päivä ja viikko-ohjelmiin sisällytettiin tietoisesti toimintoja, joiden tiedettiin olevan hänelle tärkeitä, kuten riippumatossa keinumista, pallottelua, tiettyjä leikkejä ja niin edelleen.

Romantisoinnin välttämiseksi on kuitenkin myös todettava, että henkilökuntaresurssit olivat Sebastianin päi- vätoimintakeskuksessa asiakasmääriin nähden pienet. Kun yhdellä ohjaajalla on yhtä aikaa vastuullaan monta paljon tukea tarvitsevaa asiakasta, aikaa yhden asiakkaan auttamiseen on vähemmän. Näin ollen myös päivätoimintakeskuksessa Sebastianin arkeen kuului paljon yksin oleskelua ja odottelua, vaikka hän pystyikin tässä kontekstissa olemassa olevien toimintakäytäntöjen ansiosta toteuttamaan itseään suuremmassa määrin kuin ryhmäkodissaan.

Entä sitten kunnioituksen periaate? Molemmissa organisaatioissa Sebastiania kohdeltiin pääasiassa kunnioittavasti. Kenttätyön aikana varsinkin ryhmäkodissa kuitenkin ilmeni joitakin tilanteita, joissa tästä periaatteesta poikettiin. Kyse on pienistä ja huomiota herättämättömistä teoista, joita ei välttämättä osata tunnistaa itsemääräämisoikeuden rajoittamiseksi. Kuten edellä oleva kuvaus ryhmäkodin toimintakäytännöistä tuo esiin, siellä ilmeni hetkittäin tarpeetonta fyysistä rajoittamista pyörätuolin jarrujen lukitsemisen muodossa. Lisäksi ruokailutilanteissa Sebastiania saatettiin syöttää ohikiitävien hetkien ajan jopa puoliväkisin. On myös huomionarvoista, että ruokailut toteutettiin ryhmäkodissa ja päivätoimintakeskuksessa eri tavoin. Kun ensin mainitussa ympäristössä häntä syötettiin, jälkimmäisessä hänet ohjattiin tarttumaan toisella kädellään aterimeen ja tämän jälkeen tuettiin hänen käsivarttaan kevyesti kyynärpäästä, jolloin hän pystyi itse viemään ruokaa lautaselta suuhun. Tämä antoi Sebastianille paremmat mahdollisuudet määrittää itse syömisen tahti ja milloin on syönyt riittävästi, sanalla sanoen toteuttaa itsemääräämistä myös tässä arkisessa tilanteessa. 


\section{JOHTOPÄÄTÖKSET}

Tämän artikkelin tavoitteena oli kuvata, miten syvästi kehitysvammaiset henkilöt harjoittavat itsemääräämistä omassa arjessaan. Itsemäärääminen ymmärrettiin toimintamahdollisuuksien teorian (Nussbaum 2006) valossa yksilön ja ympäristön vuorovaikutuksessa mahdollistuvana toimintana ja kaikille ihmisille kuuluvana perusoikeutena, josta nauttiminen ei edellytä mitään määrättyä yksilöllistä kyvykkyystasoa. Tästä näkökulmasta itsemäärääminen mahdollistuu syvästi kehitysvammaisille ihmisille pikemminkin muuttamalla ja mukauttamalla heidän ympäristöään kuin edellyttämällä näiltä yksilöiltä mahdottomia kehityksellisïa hyppäyksiä. Olennaista on ymmärtää ja tukea heidän tapojaan harjoittaa itsemääräämistä.

Artikkeli nosti esiin kaksi erityispiirrettä syvästi kehitysvammaisten henkilöiden tavassa harjoittaa itsemääräämistä. Ensinnäkin sille on ominaista toimijuuden esikielellinen, somaattinen ilmentäminen. Toiseksi sille on ominaista, että oman tahdon ilmaiseminen ja toteuttaminen edellyttää yhteistoimintaa kyvykkäämpien ja vastuullisten toisten kanssa. Kyseiset itsemääräämisen harjoittamisen käytännöt käsitteellistettiin tässä artikkelissa Ruddickin (1996) ja Watsonin (2016) termein "kehollisiin tahdonilmauksiin kohdistuvaksi kunnioitukseksi ja responsiivisuudeksi”.

Viime aikoina kehitysvammaisten ihmisten itsemääräämisoikeuden turvaamiseen tähtäävässä lainsäädännön ja toimintakäytäntöjen kehittämisessä on painotettu erityisesti kunnioittamisen aspektia, kun rajoittamistoimen- piteiden käytöstä on laadittu aiempaa tarkemmat säädökset (ks. Sosiaali- ja terveysministeriö 2017). Kun kyse on syvästi tai vaikeasti kehitysvammaisista henkilöistä, ei kuitenkaan riitä, että tarpeettomasta fyysisestä rajoittamisesta luovutaan. Sen ohella tarvitaan myös responsiivisuutta eli näiden ihmisten kehollisten tahdonilmausten jatkuvaa esiin kutsumista, tarkkailua ja tulkintaa sekä niiden täytäntöönpanoa.

Sebastianin tapauksessa hänen arkensa rakentumisen kannalta keskeisten palvelujen tuottamisesta vastaavien organisaatioiden - päivätoimintakeskuksen ja ryhmäkodin - toimintakäytännöt poikkesivat toisistaan merkittävästi juuri responsiivisuuden osalta. Erityisesti hänen ryhmäkotinsa toimintakäytäntöjä leimasi responsiivisuuden puute, millä oli kouriintuntuvia seurauksia hänen mahdollisuuksiinsa elämää omannäköistään elämää. Kyseinen organisaatio ei liene tässä suhteessa pelkkä anomalia. Todennäköisempää on, että samankaltaisia puutteita esiintyy muidenkin vammaispalveluorganisaatioiden toimintakäytännöissä, semminkin kun vallitseva itsemääräämisoikeuskäsitteistö ei tällä hetkellä tunnista vaikeimmin kehitysvammaisten henkilöiden itsemääräämisen harjoittamiseen liittyviä erityisiä tarpeita, kuten tämän artikkelin johdantoluvussa todettiin. Tilanne mahdollistaa suuren vaihtelun organisaatioiden tavoissa tukea vammaisten asiakkaiden itsemääräämistä.

Tässä artikkelissa rakennettu teoreettinen ja käsitteellinen viitekehys antaa mahdollisuuden laajentaa käsitystä autonomiasta siten, että sillä voidaan nähdä olevan relevanssia myös syvästi kehitysvammaisille ihmisille. Lisäksi se 
luo suuntaviivoja sosiaalihuollon toimintakäytäntöjen kehittämiselle laajasti toisten tuesta ja hoivasta riippuvaisten ihmisten itsemääräämisoikeutta tukeviksi. Hoivan antajien toiminnan ja asennoitumisen merkitystä tässä tilanteessa ei voi korostaa liikaa. Jatkossa olisi panostettava rajoittamistoimenpiteiden säätelyn ohella myös responsiivisten toimintakäytäntöjen kehittämiseen esimerkiksi henkilökunnalle tarjottavan koulutuksen ja esimiestuen sekä yhteisen arvotyöskentelyn avulla. Samalla on tärkeää varmistaa, että henkilöstöresurssit ovat tasolla, jossa on myös käytännössä mahdollista ottaa aikaa responsiivisuuden edellyttämään, hoivatoimenpiteistä irralliseen kontaktiin asiakkaiden kanssa.

Vaikka tässä artikkelissa huomio on ollut syvästi kehitysvammaisen henkilön mahdollisuuksissa vaikuttaa omaan arkeensa ja saamaansa tukeen, on hyvä muistaa, että Sebastianin kaltaisen, syvästi kehitysvammaisen henkilön näkökulmasta on aivan yhtä tärkeää, että häntä ei jätetä yksin vastuuseen oman arkensa ja palvelujensa suunnittelusta ja organisoinnista. Jos hänen ympärillään olevat ihmiset eivät esimerkiksi suunnittelisi Sebastianin ruokavaliota, hankkisi tarvittavia raaka-aineita, valmistaisi hänen aterioitaan ja auttaisi häntä syömään, tällä olisi Sebastianille vakavia seurauksia - hän ei yksinkertaisesti selviytyisi.Tällaisia hoivan ja huolenpidon prosesseja voidaan kuitenkin muovata hoivan tarvitsijan itsemääräämisoikeutta paremmin tukeviksi huomioimalla keholliset tahdonilmaukset esimerkiksi siten, että hänen annetaan määrittää syömisen tahti ja määrä sekä joiltakin osin myös aterioiden koostumus.
Itsemääräämisoikeuden näkökulmasta sellainen hoiva ja huolenpito, jonka lähtökohtana ei ole hoivan tarvitsijan ilmaisemat toiveet, voidaan nähdä kontrollina ja rajoittamisena. Nussbaumin (2006) ja Ruddickin (1996) kaltaiset teoreetikot katsovat, että tällaisesta kontrollista ja rajoittamisesta ei ole mielekästä luopua kokonaan, koska olisi vastuutonta vain katsoa sivusta, jos toisen ihmisen kyky huolehtia itsestään pettää tai jos hän on vaaraksi itselleen tai muille. Samalla he kuitenkin korostavat, että kaikenlainen kontrolli ja pakottaminen tulee rajata minimiin ja yhdistää toimenpiteisiin, joiden tarkoituksena on osallistaa kyseinen henkilö päätöksentekoon niin usein ja paljon kuin mahdollista. Tämä herättää kysymyksen, milloin ja millaista kontrollia ja rajoittamista voidaan pitää legitiiminä. Tähän kysymykseen olisikin tärkeää pureutua syvemmin jatkotutkimuksessa.

\section{KirjallisuUs}

Bigby, Christine \& Douglas, Jacinda \& Carney, Terry \& Then, Shih-Ning \& Wiesel, Ilan \& Smith, Elizabeth (2017) Delivering decision making support to people with cognitive disability. What has been learned from pilot programs in Australia from 2010 to 2015. Australian Journal of Social Issues 52 (3), 222-240. https://doi. org/10.1002/ajs4.19

Björnsdóttir, Kristín \& Stefánsdóttir, Gudrún V. \& Stefánsdóttir, Ástridur (2015) 'It's my life': Autonomy and people with intellectual disabilities. Journal of Intellectual Disabilities 19 (1), 5-21. https://doi. org/10.1177/1744629514564691

Blanck, Peter \& Martinis, Jonathan G. (2015) "The Right to Make Choices": The National Resource Center for Supported Decision-Making. Inclusion 3 (1), 24-33. https://doi.org/10.1352/23266988-3.1.24 
Ferguson, P.M. \& Ferguson, D.L. (2001) Winks, blinks, squints and twitches: Looking for disability, culture and selfdetermination through our son's left eye. Scandinavian Journal of Disability Research 3 (2) 71-90. https://doi. org/10.1080/15017410109510777

Finlay, W.M.L. \& Walton, Chris \& Antaki, Charles (2008a) Promoting choice and control in residential services for people with learning disabilities. Disability \& Society 23 (4), 349-360. https://doi. org/10.1080/09687590802038860

Finlay, W.M.L. \& Antaki, Charles \& Walton, Chris (2008b) The dilemma for staff in 'playing a game' with a person with profound intellectual disabilities: Empowerment, inclusion and competence in interactional practice. Sociology of Health and Illness 30 (4), 531- 549. https://doi. org/10.1111/j.1467-9566.2007.01080.x

Geertz, Clifford (1973) The Interpretation of Cultures. New York: Basic Books.

Mietola, Reetta \& Miettinen, Sonja \& Vehmas, Simo (2017) Voiceless subjects? Research ethics and persons with profound intellectual disabilities. International Journal of Social Research Methodology 20 (3), 263-274. https://doi.org/10.1 080/13645579.2017.1287872

Nussbaum, Martha (2006) Frontiers of Justice. Disability, Nationality, Species Membership. Cambridge, MA: The Belknap Press of Harvard University Press. https:// doi.org/10.2307/j.ctv1c7zftw

Nussbaum, Martha (2011) Creating capabilities: The human development approach. Cambridge, MA: The Belknap Press of Harvard University Press. https://doi. org/10.4159/harvard.9780674061200

Paara, Erkki (2005) Vammaispalvelujen järjestäminen ja osaaminen. Selvitys vammaislakien yhdistämisestä. Helsinki: Sosiaali- ja terveysministeriö.

Porter, Jill \& Ouvry, Carol \& Morgan, Maggie \& Downs, Caroline (2001) Interpreting the communication of people with profound intellectual and multiple disabilities. British Journal of Intellectual Disabilities 29 (1), 12-16. https://doi. org/10.1046/j.1468-3156.2001.00083.x

Ruddick, Sara (1996) Injustice in families. Assault and domination. Teoksessa Nancy E. Snow (toim.) In the company of others. Perspectives on community, family, and culture. Lanham, MD: Rowman and Littlefield Publishers, 65-101.

Sosiaali- ja terveysministeriö (2012) Valtioneuvoston periaatepäätös kehitysvammaisten henkilöiden yksilöllisen asumisen ja palvelujen turvaamisesta. Helsinki: Sosiaali- ja terveysministeriö.

Sosiaali- ja terveysministeriö (2017) Kehitysvammalain muutokset. Helsinki: Sosiaali- ja terveysministeriö.

Suomen YK-liitto (2015) YK:n yleissopimus vammaisten henkilöiden oikeuksista. Helsinki: Suomen YK-liitto.

Vorhaus, John (2013) Capability, freedom, and profound disability. Disability \& Society 28 (8), 1047-1058. https://doi.org/ 10.1080/09687599.2012.758036

Ware, Jean (2004) Ascertaining the views of people with profound and multiple intellectual disabilities. British Journal of Intellectual Disabilities 32 (4), 175 179. https://doi.org/10.1111/j.14683156.2004.00316.x

Watson, Joanne (2016) Assumptions of decision-making capacity. The role supporter attitudes play in the realisation of article 12 for people with severe or profound intellectual disability. Laws 5 (1), 6. https:// doi.org/10.3390/laws5010006

World Health Organisation (1992) The ICD-10 classification of mental and behavioural disorders. Geneva:WHO.

Young, Iris M. (1997) Intersecting voices: Dilemmas of gender, political philosophy, and policy. Princeton: Princeton University Press. https://doi. org/10.1515/9780691216355 